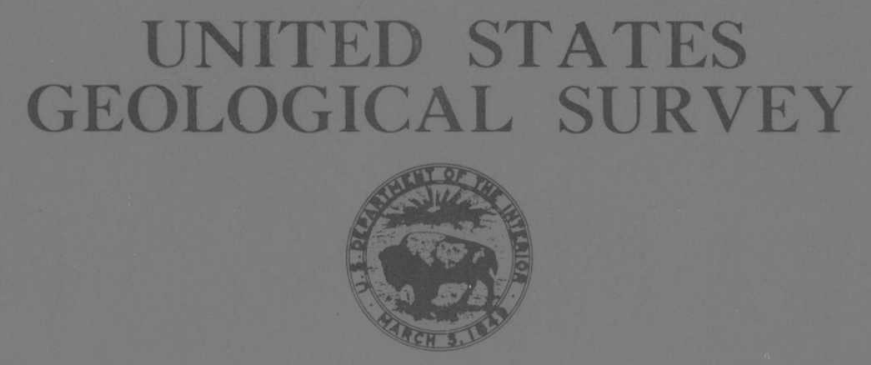

\title{
DATA SUMMARY OF JUNE-JULY 1975 FLOODS IN EASTERN NORTH DAKOTA AND NORTHWESTERN MINNESOTA
}

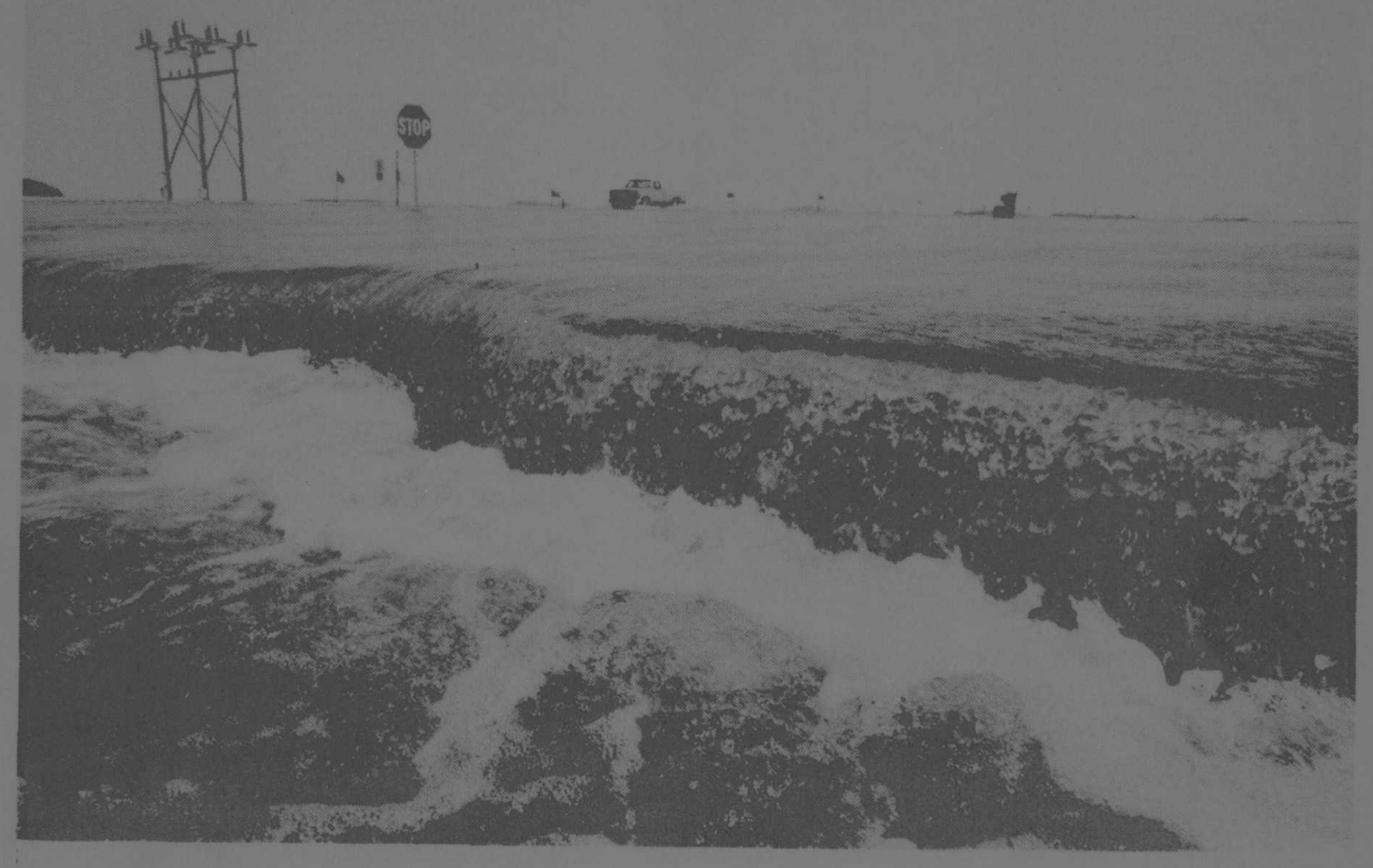


ON THE COVER

Floodwaters at intersection of U.S. Highway 75 with a Clay County road near Kragnes, Minn. The photograph is by Colburn Hvidston II and appeared in the July 4 , 1975 issue of the Fargo-Moorhead paper titled "The Forum". 


\section{UNITED STATES \\ DEPARTMENT OF THE INTERIOR \\ GEOLOGICAL SURVEY}

DATA SUMMARY OF JUNE-JULY 1975

FLOODS IN EASTERN NORTH DAKOTA

AND NORTHWESTERN MINNESOTA

By K. L. Lindskov

Open-File Report 75-565

Bismarck, North Dakota

and

St. Paul, Minnesota

September 1975 


\section{CONTENTS}

Conversion $f a c t o r s \ldots \ldots \ldots \ldots \ldots \ldots \ldots \ldots \ldots \ldots \ldots \ldots \ldots$

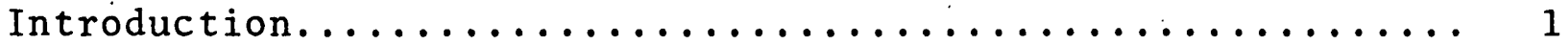

The storm................................... 1

Summary of flood data......................... 3

Peak stages and discharges.................... 3

Sediment concentrations..................... 13

Remote-sensing data available from EROS Data Center.... 13

\section{ILLUSTRATIONS}

Page

Figure 1. Isohyetal map of total rainfall during

June $28-30$ and July $1-2,1975 \ldots \ldots \ldots \ldots \ldots \ldots \ldots \ldots \ldots$

2. Map showing locations of flood-measurement sites.. 4

3. Graph of June-July 1975 floods compared with

maximum floods previously determined..........

4. Hydrographs of daily mean flow at selected

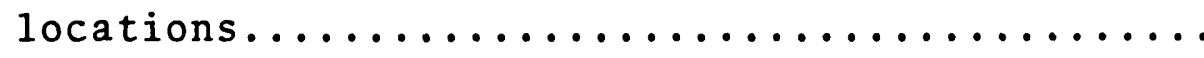




\section{TABLES}

Page

Table 1. Summary of flood stages and discharges......... 5

2. Summary of sediment data collected during the

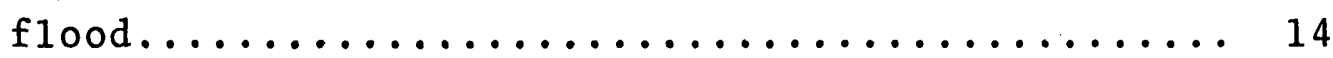

3. Summary of remote sensing data on 1975 Red

River of the North flood available through

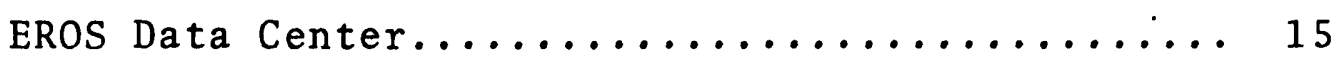




\section{CONVERSION FACTORS}

The following factors may be used to convert the English units published herein to the International System of Units (SI).

Multiply English units

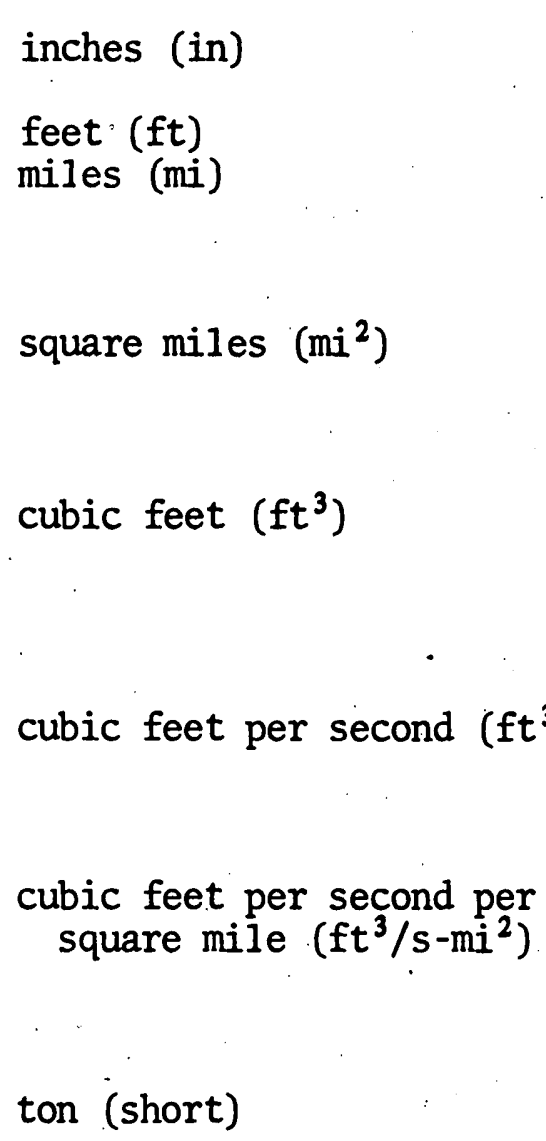

ton (short)

Mass

By

To obtain SI units

Length

$$
\begin{gathered}
25.4 \\
.0254 \\
.3048 \\
1.609
\end{gathered}
$$

Area

2.590

Volume

28.32

.02832

Flow

.9072

\author{
millimetres (mm) \\ metres (m) \\ metres (m) \\ kilometres $(\mathrm{km})$
}

square kilometres $\left(\mathrm{km}^{2}\right)$

cubic decimetres $\left(\mathrm{dm}^{3}\right)$

cubic metres $\left(\mathrm{m}^{3}\right)$

liters per second ( $1 / \mathrm{s})$ cubic decimetres per second $\left(\mathrm{dm}^{3} / \mathrm{s}\right)$ cubic metres per second $\left(\mathrm{m}^{3} / \mathrm{s}\right)$ cubic metres per second per square kilometre $\left(\mathrm{m}^{3} / \mathrm{s}-\mathrm{km}^{2}\right)$

tonne $(t)$ 


\section{INTRODUCTION}

Torrential rains during late June and early July 1975, combined with wet antecedent conditions, caused severe flooding, mainly along the lower reaches of the Sheyenne and Maple Rivers and their tributaries in North Dakota, and in the Buffalo and Wild Rice River basins in Minnesota. The Red River of the North from the Fargo-Moorhead area to the Halstad, Minnesota area was also severely flooded. Because much of the region is extremely flat, large areas of the two States were inundated by flood waters. Damage, mostly agricultural, was widespread and damage estimates exceeded a quarter of a billion dollars.

Local, State, and Federal officials need factual information to evaluate, coordinate, and manage programs concerned with flood losses. The purpose of this report is to provide quickly a summary of some of the basic data collected on the June-July 1975 floods. Only a part of the information collected by the U.S. Geological Survey on the extent and magnitude of the floods is presented. This information includes the magnitude and fre quency of the instantaneous maximum stages (water-surface elevations) and flow rates for 62 sites, measured sediment loads at 7 sites, and hydrographs of daily mean flow at 6 sites. Additional streamflow information associated with the floods will be provided subsequently in annual data releases of the Geological Survey. The report also describes availability of graphic or photographic data depicting the areal extent of inundation. Those data may be obtained from the Applications Assistance Branch, EROS Data Center, U.S. Geological Survey, Sioux Falls, S. Dak. 57198.

Only a minimal amount of rainfall data are summarized in this report to aid in documenting the flood event. These data were provided by the National Oceanic and Atmospheric Administration (NOAA), U.S. Department of Commerce, and by the Minnesota State office of Climatology. This assistance in providing the data and in reviewing the form of its presentation is appreciated.

\section{THE STORM}

Two separate storms contributed to the June-July flooding. The first dumped more than 4 inches (102 millimetres) of rain during June 28-30 over an area extending from the JamestownLa Moure area, North Dakota on the west, between Abercrombie and Fargo on the south and north, and to Detroit Lakes, Minn. on the east (fig. 1), about 6,000 square miles $(16,000$ square kilometres). Parts of La Moure, Barnes, Ransom, Cass, and Richland Counties in North Dakota, and Clay, Norman, Becker, and Otter Tail Counties in Minnesota received rainfall exceeding 10 inches (254 millimetres) for the 3 -day period. An unofficial gage near Leonard, N. Dak. registered 20 inches 


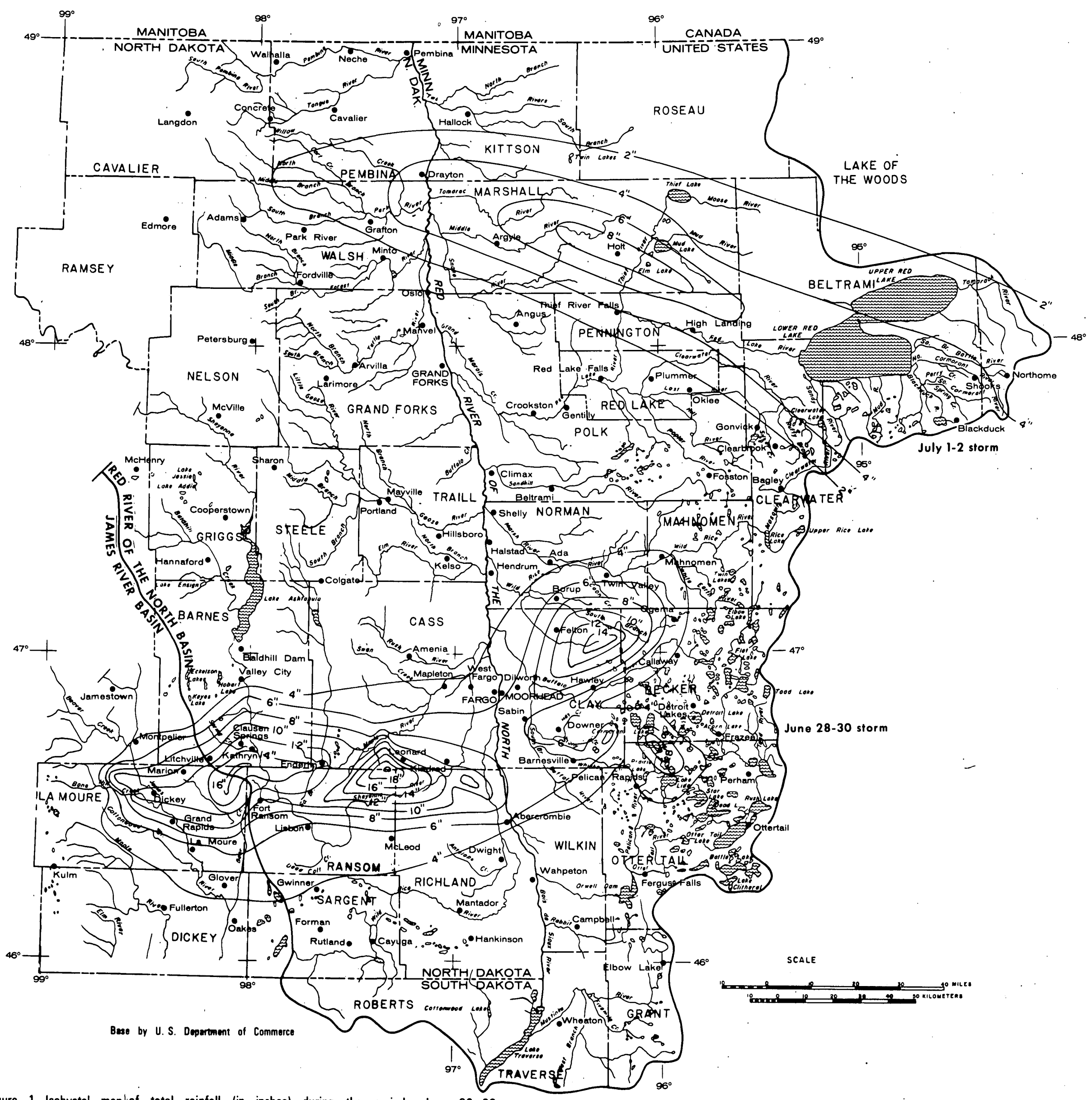

Figure 1.--Isohyetal maplof total rainfall (in inches) during the periods June 28-30 and July 1-2, 1975" (Based on data provided by National Oceanic and Atmospheric Administration, U. S. Dept. of Commerce, and by Minnesota State Office of Climatology.) 
(508 millimetres) of rain. The first storm was responsible for flooding along the Red River of the North from the Fargo-

Moorhead area to Grand Forks, N. Dak.

During July 1-2, a second storm produced high rainfall along a wide band from Drayton, N. Dak. to Lower Red Lake, Minn. The July storm was not as severe as the June storm, a1 though 8,000 square miles $(21,000$ square kilometres), mostly in Minnesota, received more than 2 inches (51 millimetres) of rain (fig. 1). Holt, Minn., located north of Thief River Falls, reported 8 inches (203 millimetres), the largest amount. The July storm caused significant flooding along tributaries entering the Red River of the North in the extreme northwestern part of Minnesota, including the Red Lake River basin.

SUMMARY OF FLOOD DATA

Peak stages and discharges

Peak stages and discharges were documented at 62 sites 10cated in areas of significant flooding. Locations of the sites are shown on figure 2. The stream basins exclusively in North Dakota that drain to the Red River include the Wild Rice, lower Sheyenne, and lower Maple. A few sites are in the James River basin which drains to the Missouri River. The Minnesota stream basins are mainly the Buffalo, Wild Rice, Marsh, Sandhill, Red Lake, and Snake. All gaging stations on the main stem of the Red River of the North from Wahpeton to Drayton, N. Dak. are included.

A summary of maximum flood stages and discharges at 47 sites (fig. 2) in the regular stream-gaging network and at 15 miscellaneous sites on smaller drainage areas is presented in table 1 for both the maximum flood previously known and the maximum experienced during the June-July 1975 floods. The relative magnitude of the 1975 floods compared to the maximums previously known are shown in figure 3. The 1975 floods exceeded the maximums previously known at 18 of 47 sites having 10 or more years of record, largely on tributary streams. The Red River of the North at Halstad, Minn. was the only main-stem station where the June-July floods exceeded the maximum previously known. The discharges for the 1975 peaks exceeded the 100-year flood (the flood expected to be equaled or exceeded once every 100 years on the average) at three sites within the regular network.

In addition to inundation of large areas, the duration of flooding was long, magnifying the damage. The Red River of the North at Fargo and Grand Forks, N. Dak. and at Halstad, Minn. remained above flood stage for about 10 days, as shown on figure 4. The duration of flooding for smaller streams like the South Branch Buffalo River at Sabin, Minn. was about. 3 days. 


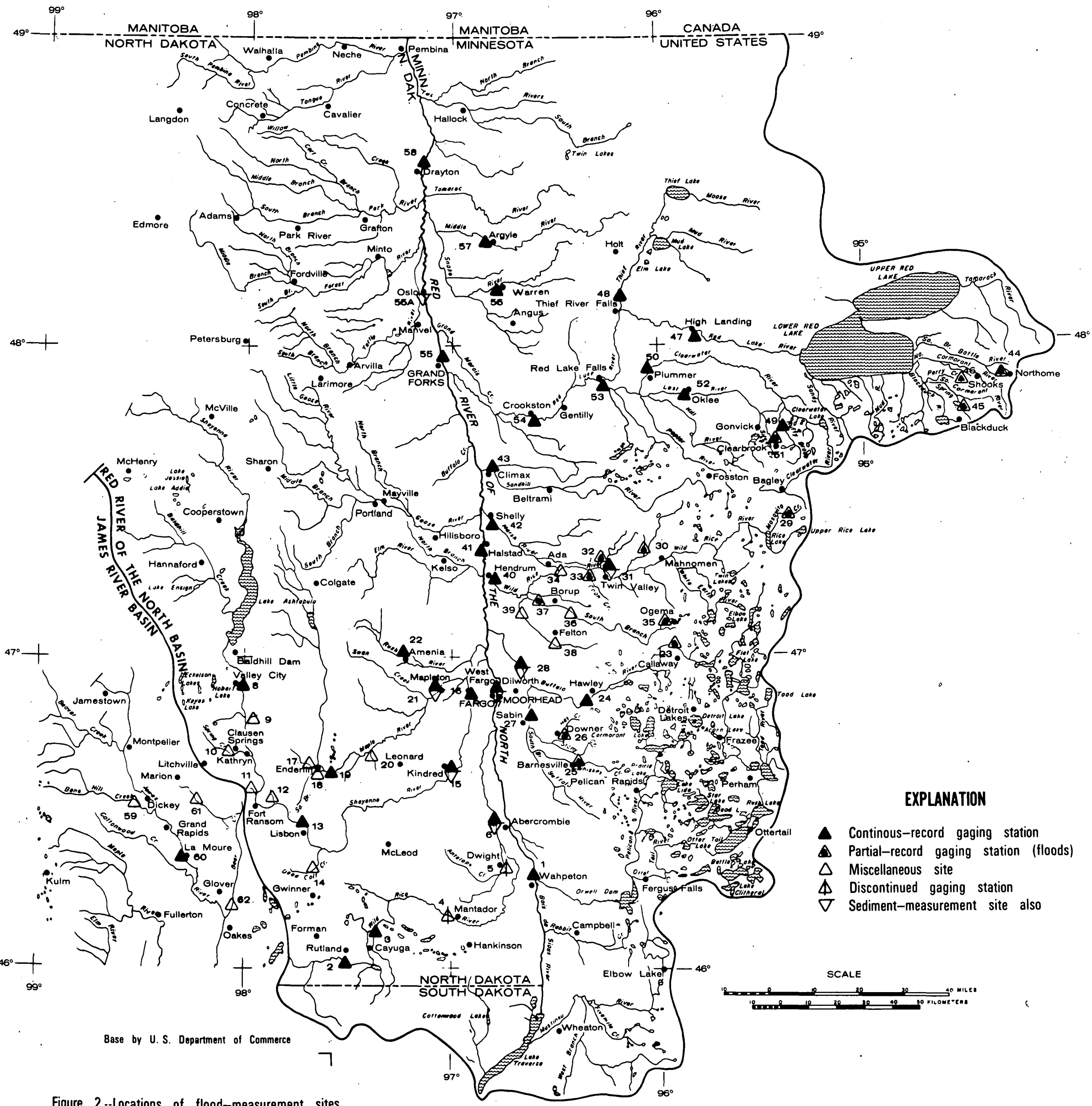

Figure 2.--Locations of flood-measurement sites. 


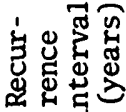

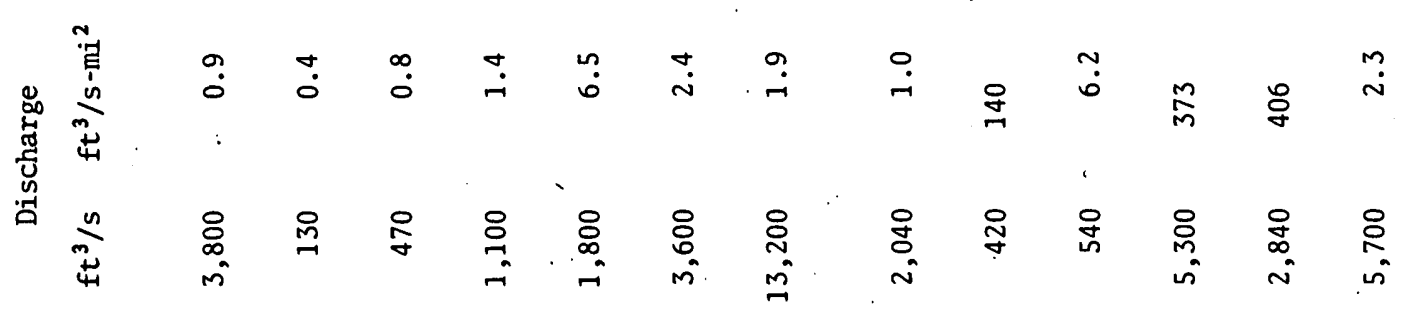

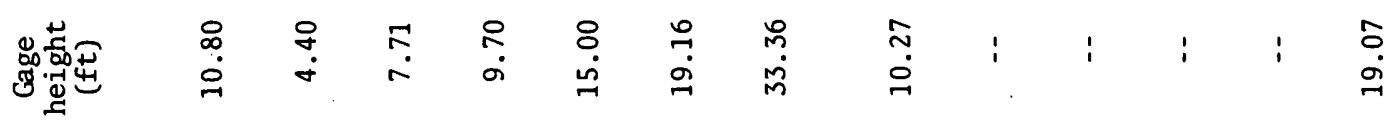

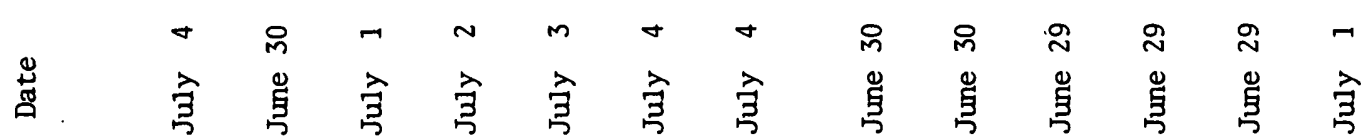

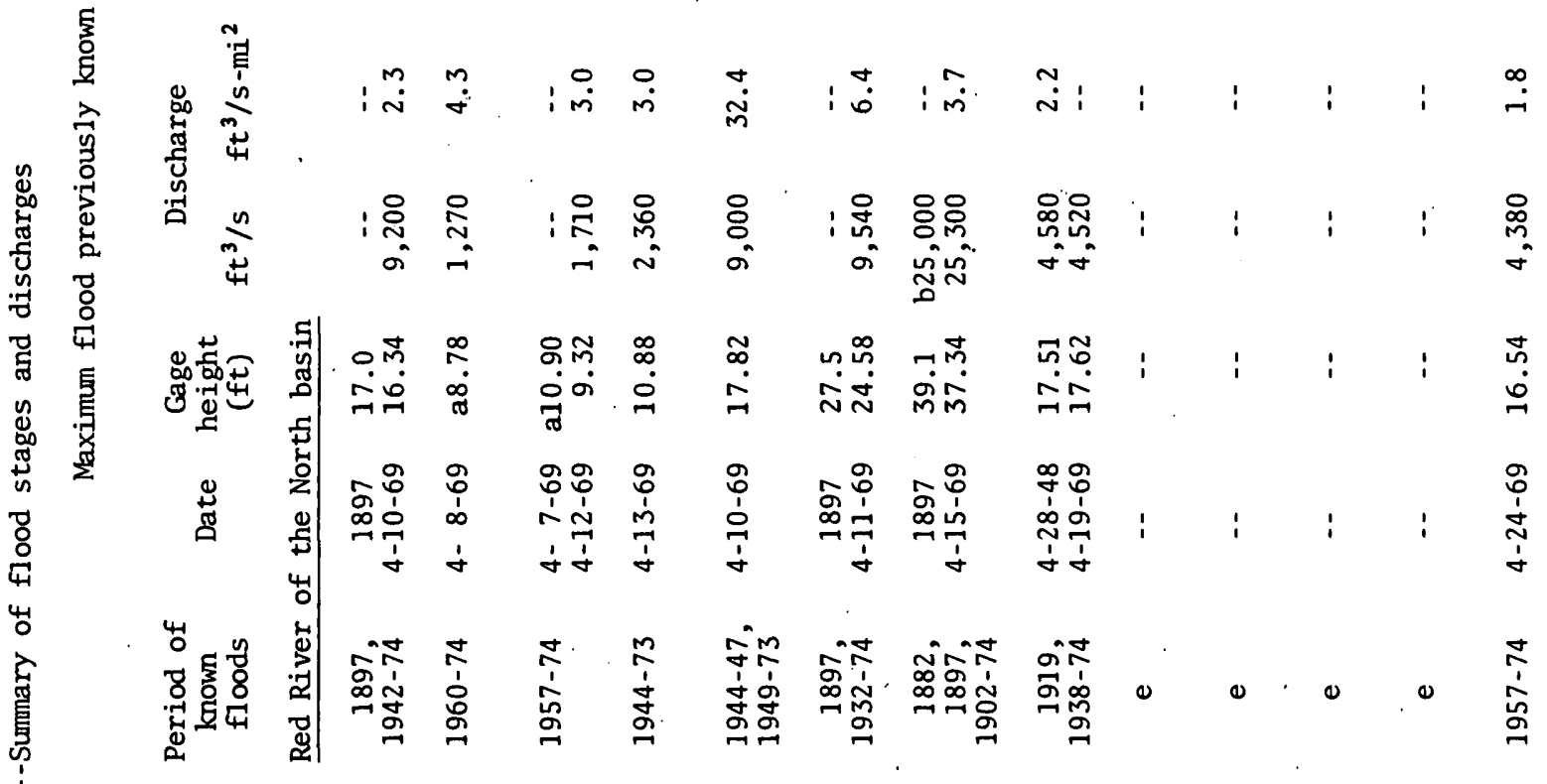

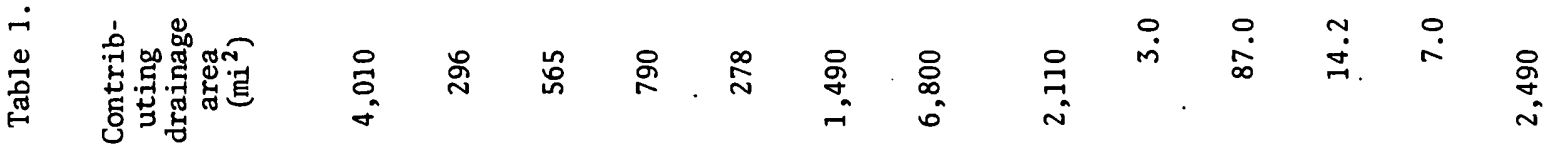

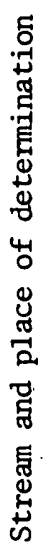

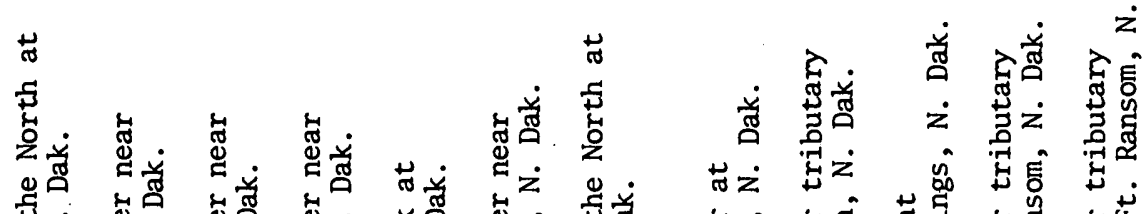

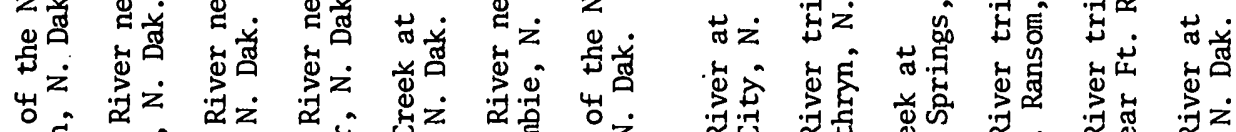

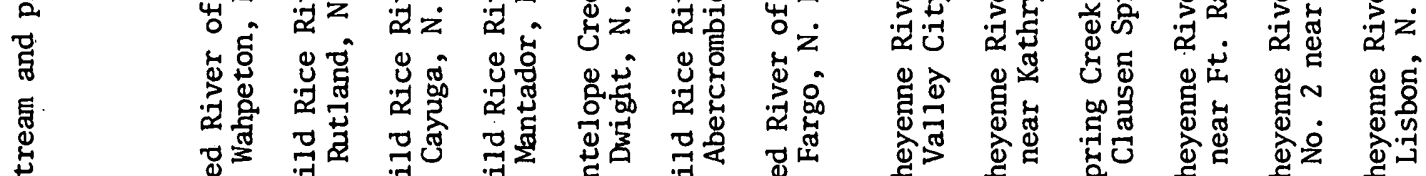

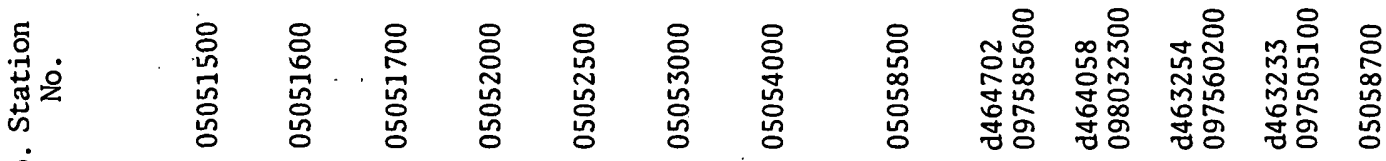

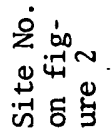



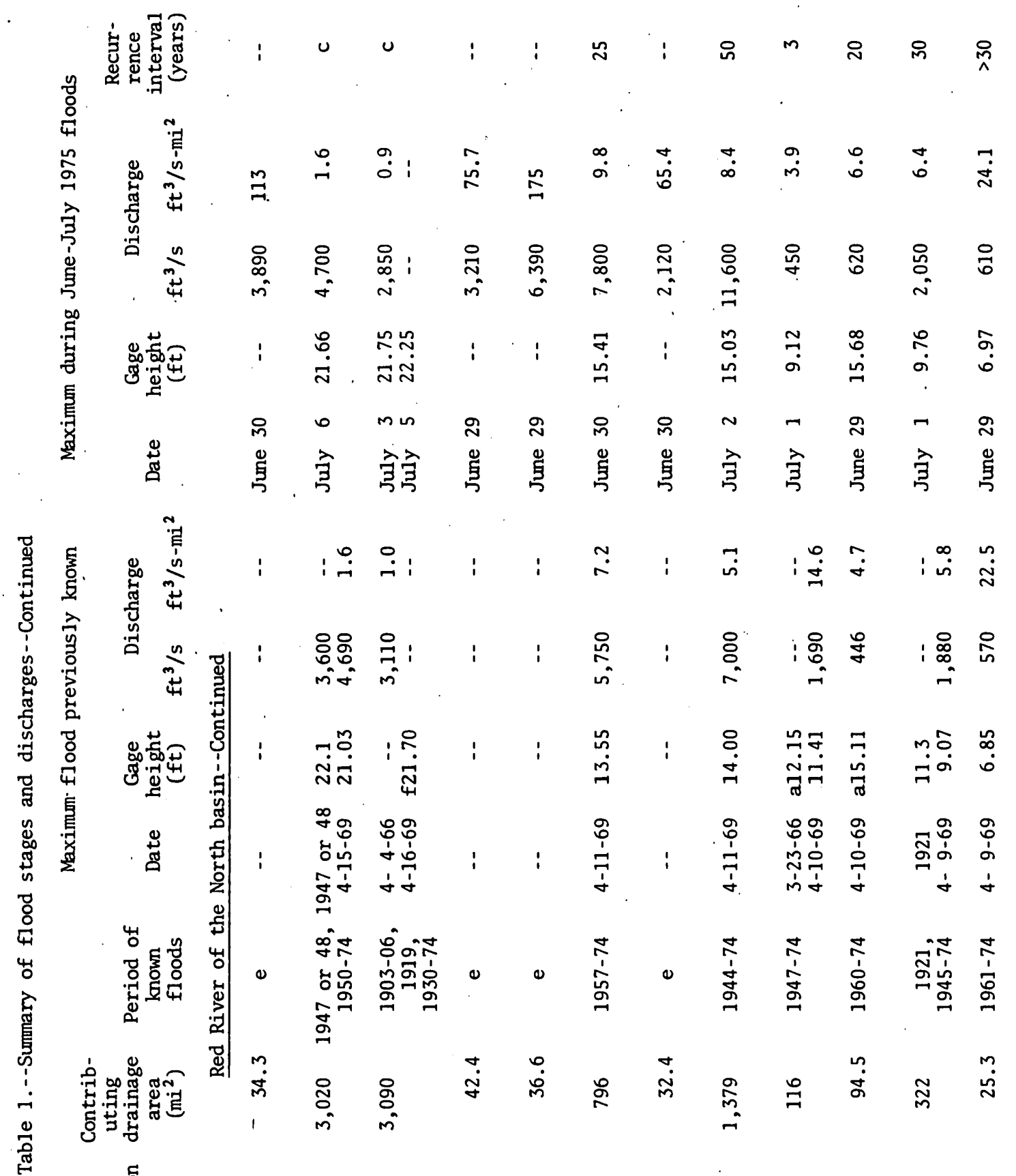

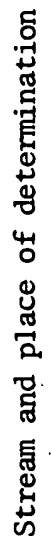

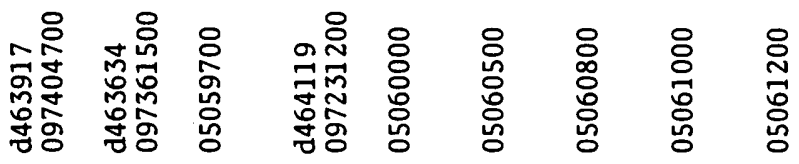

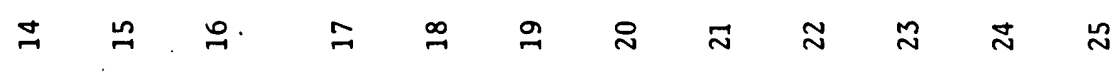




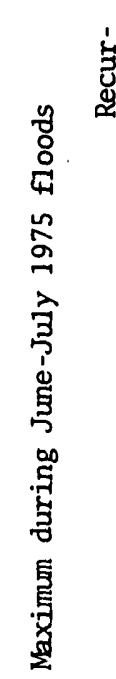

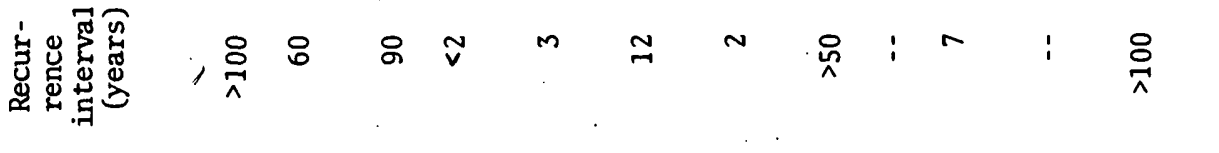

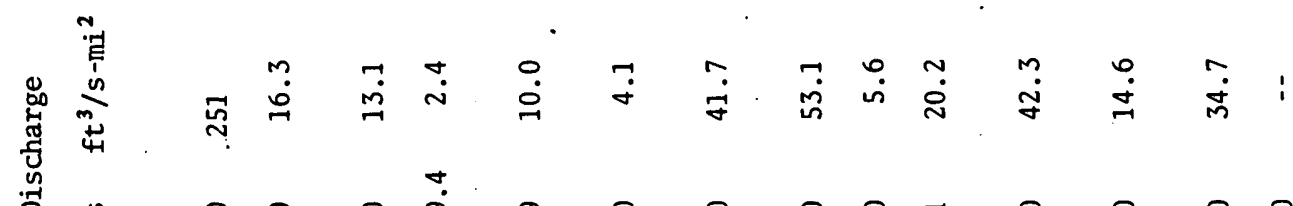

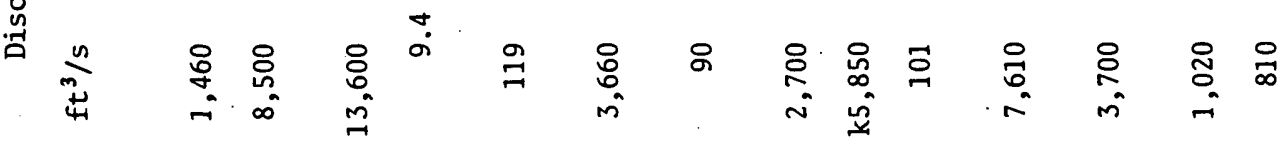

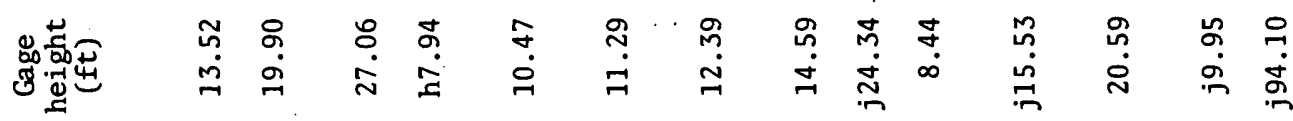

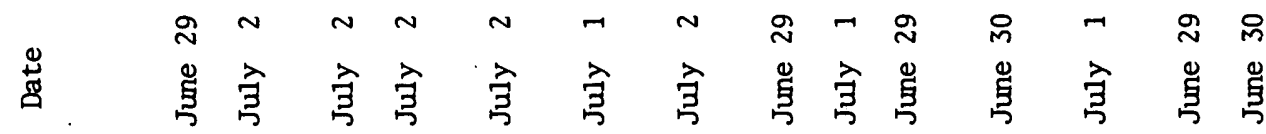
暨离

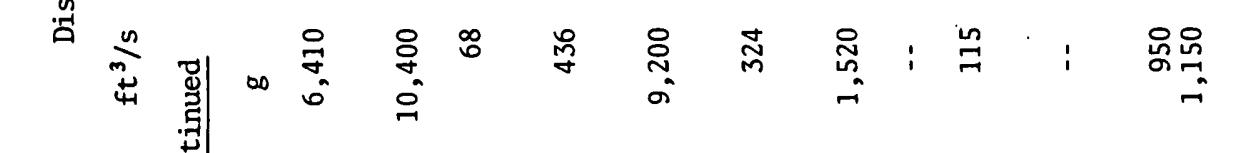

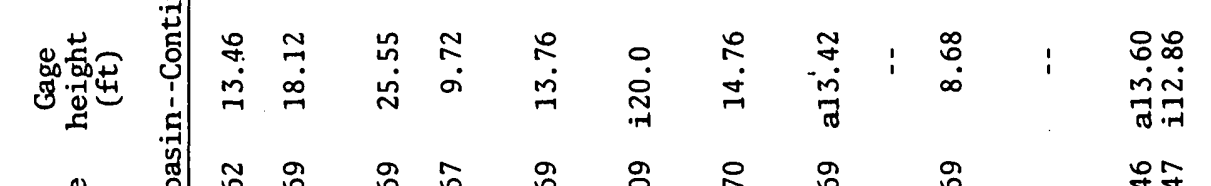

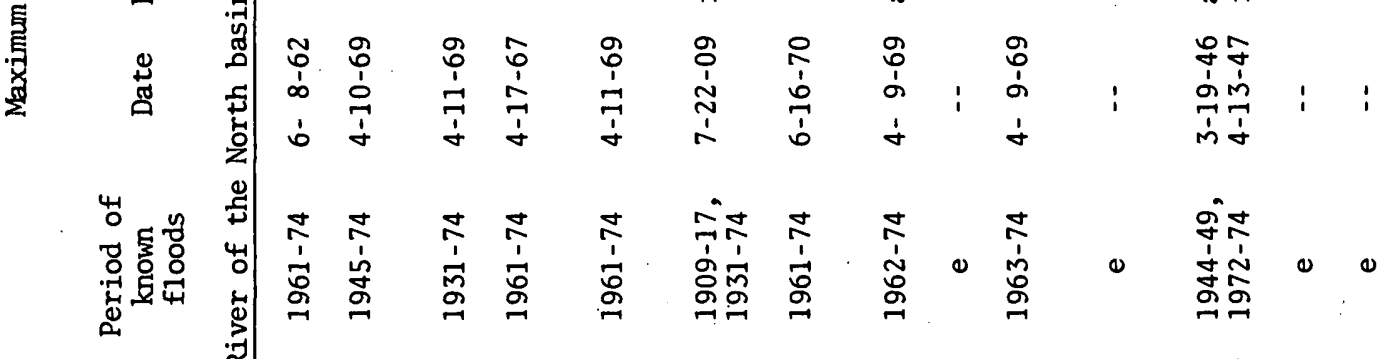

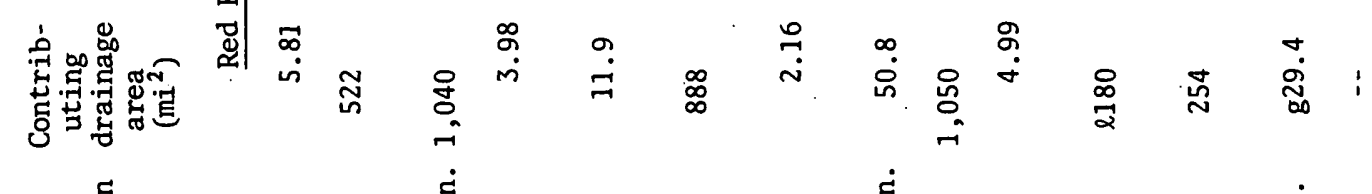

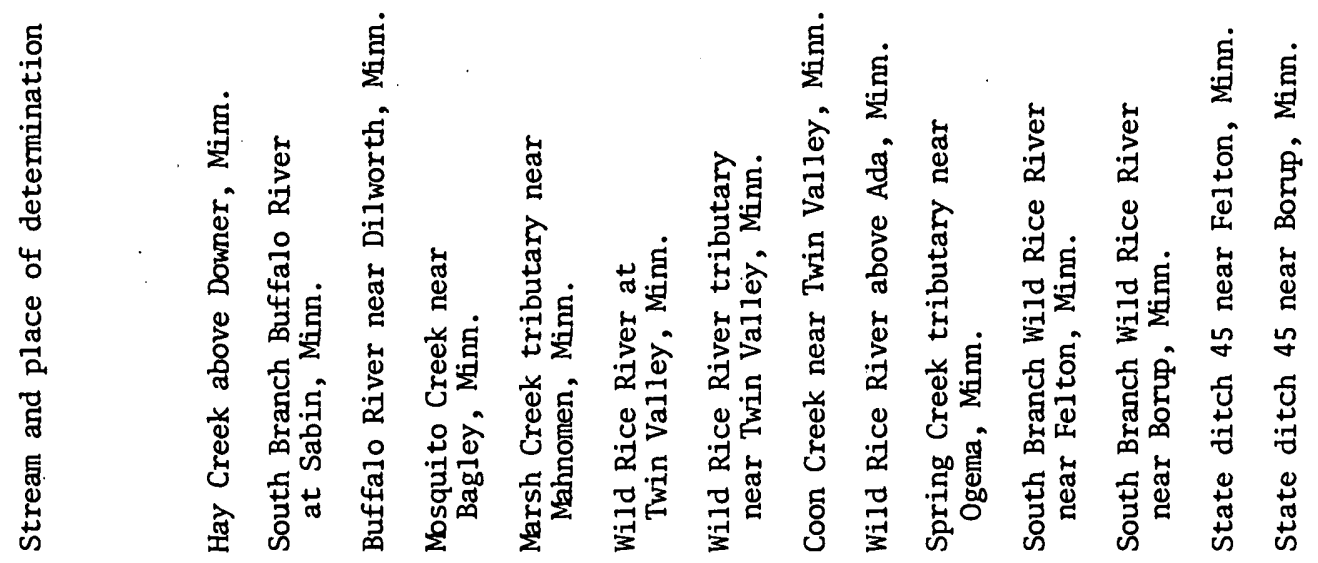

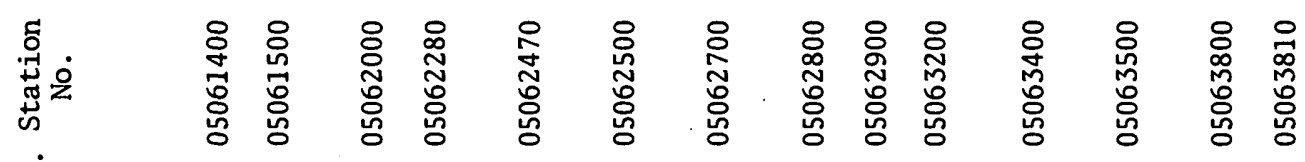

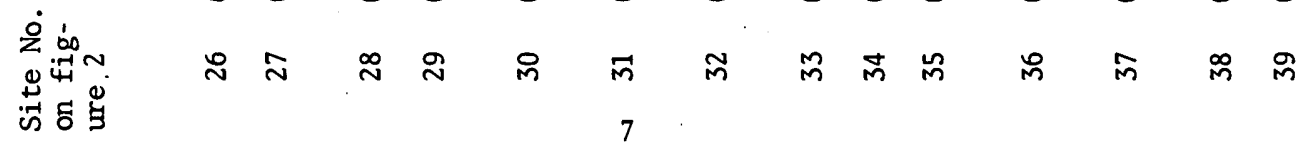




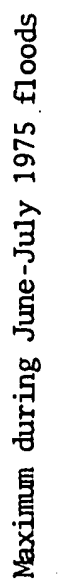

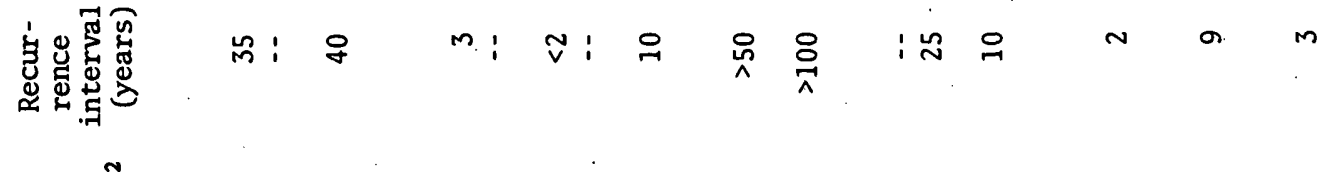

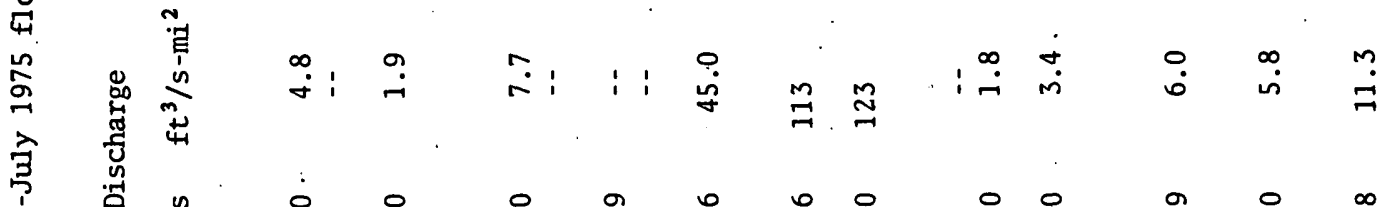

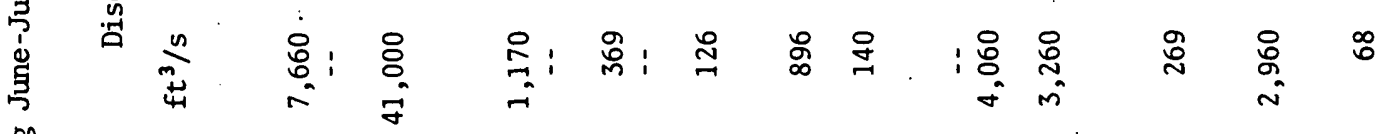

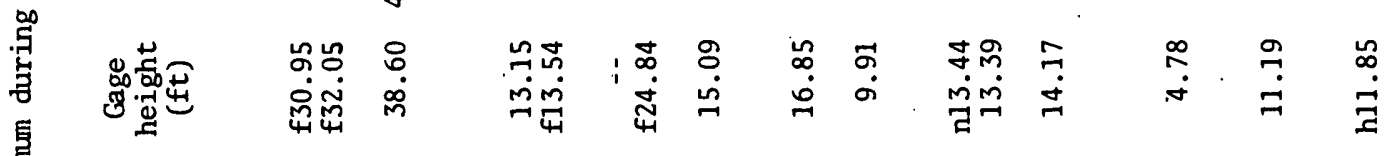

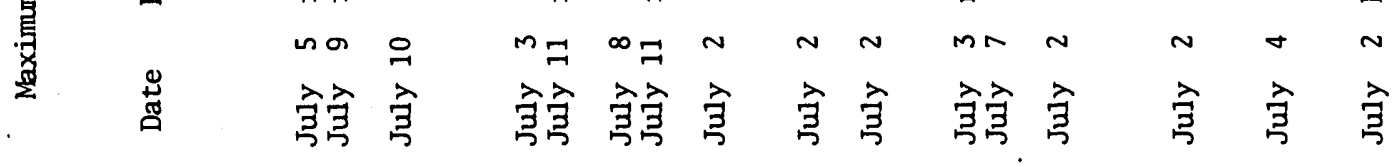

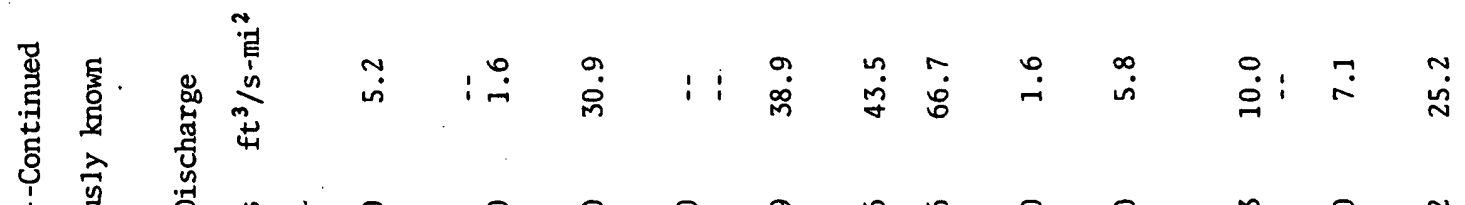

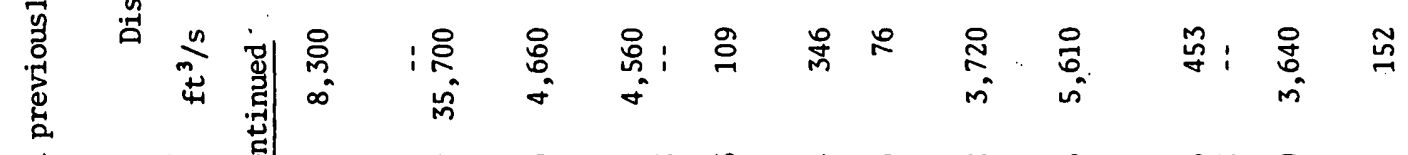

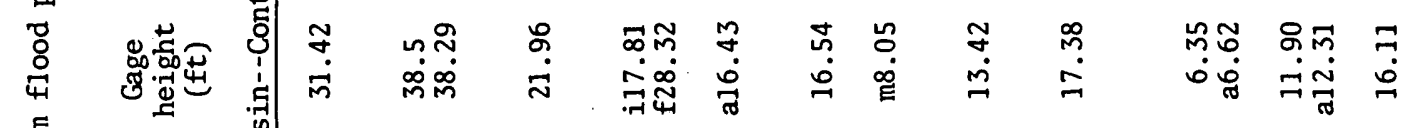

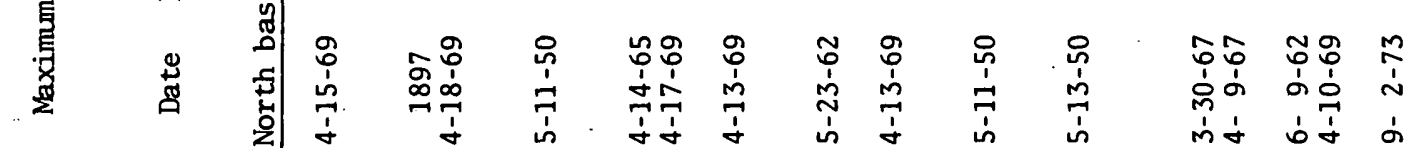
\& 4 क

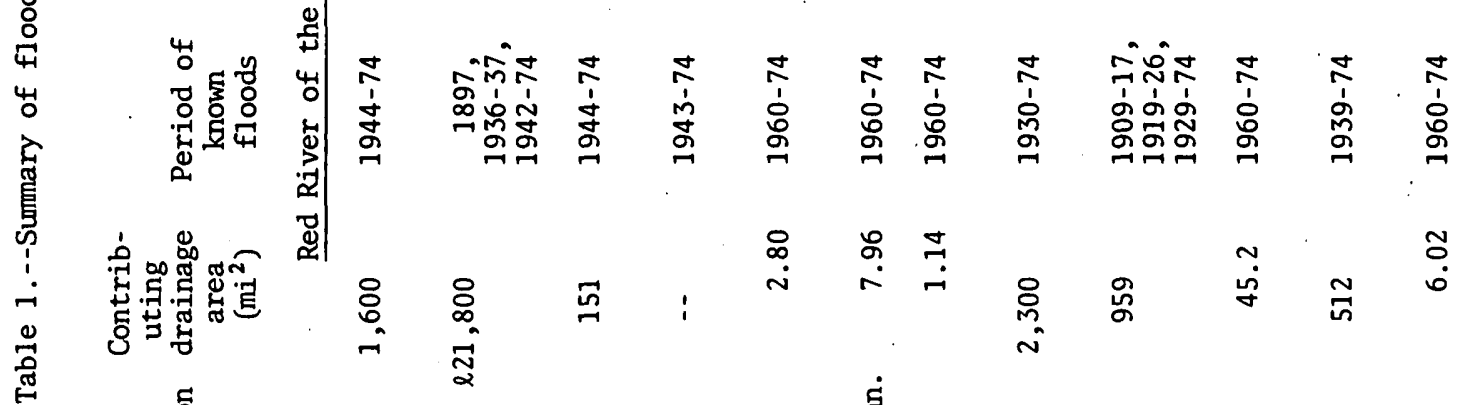
章

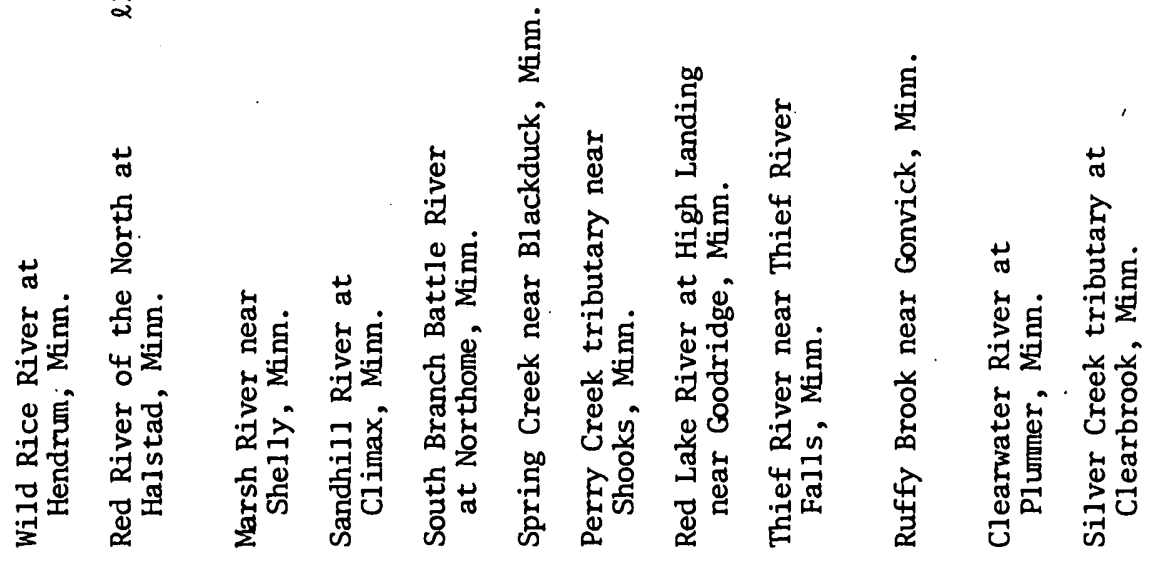

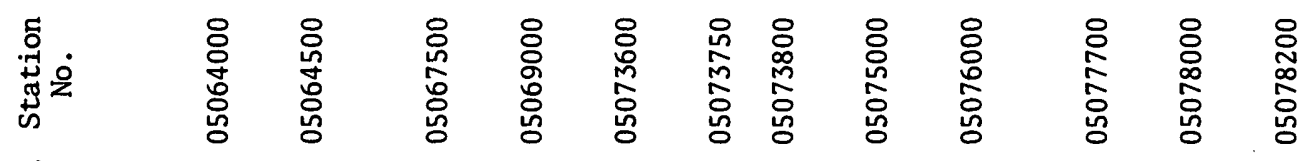

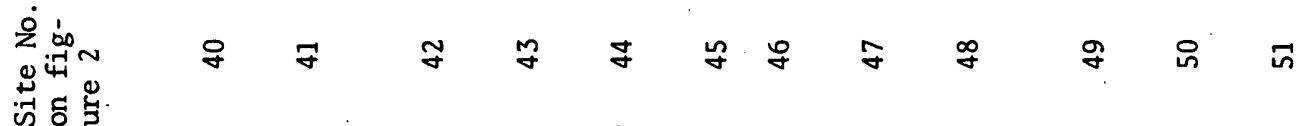




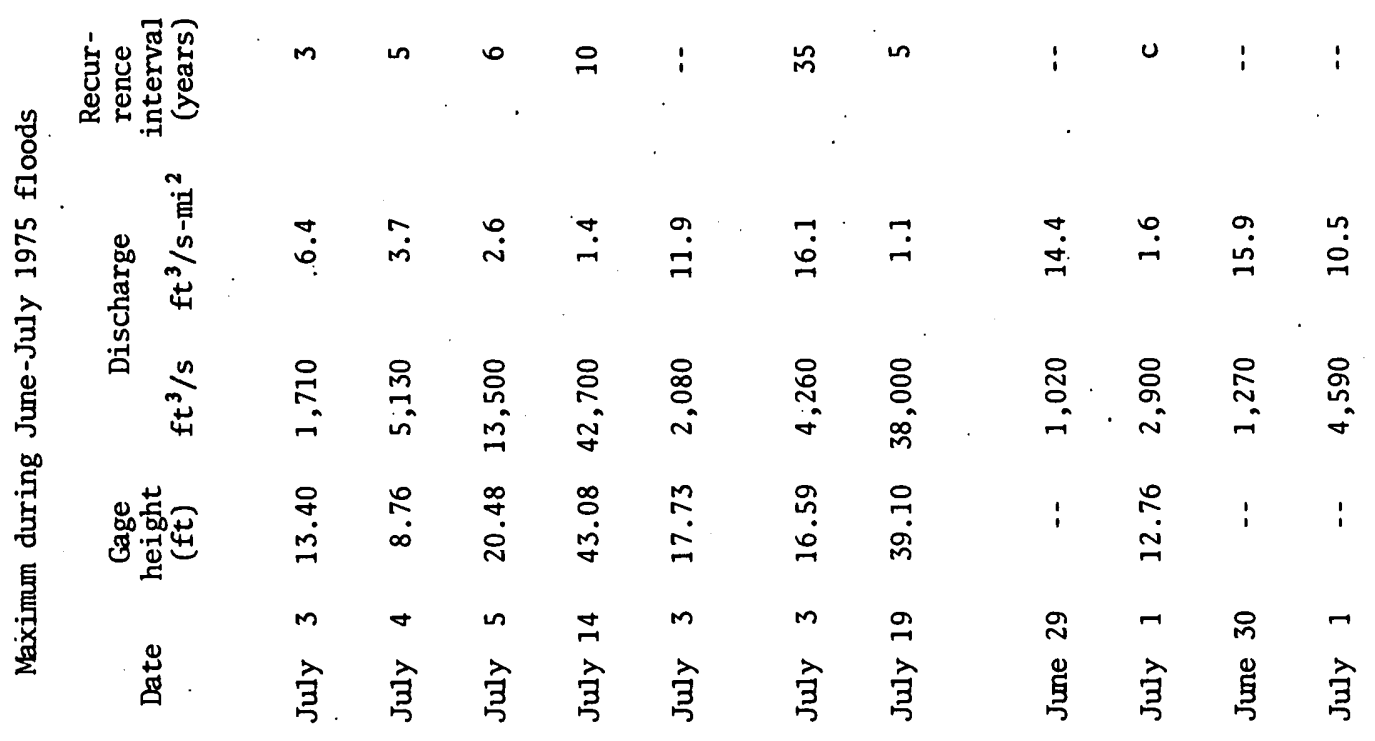

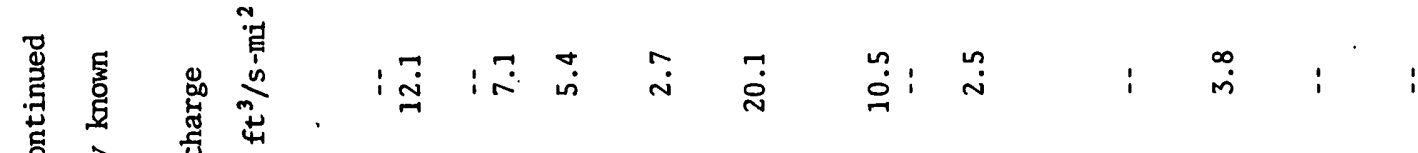

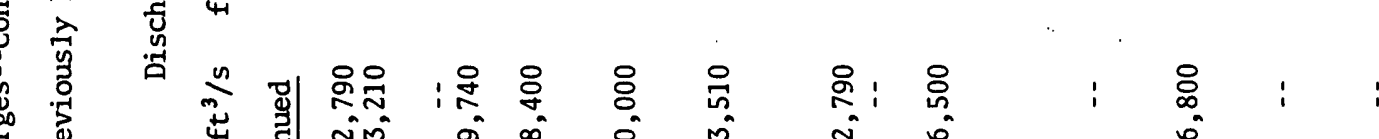
常 政

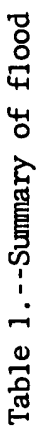

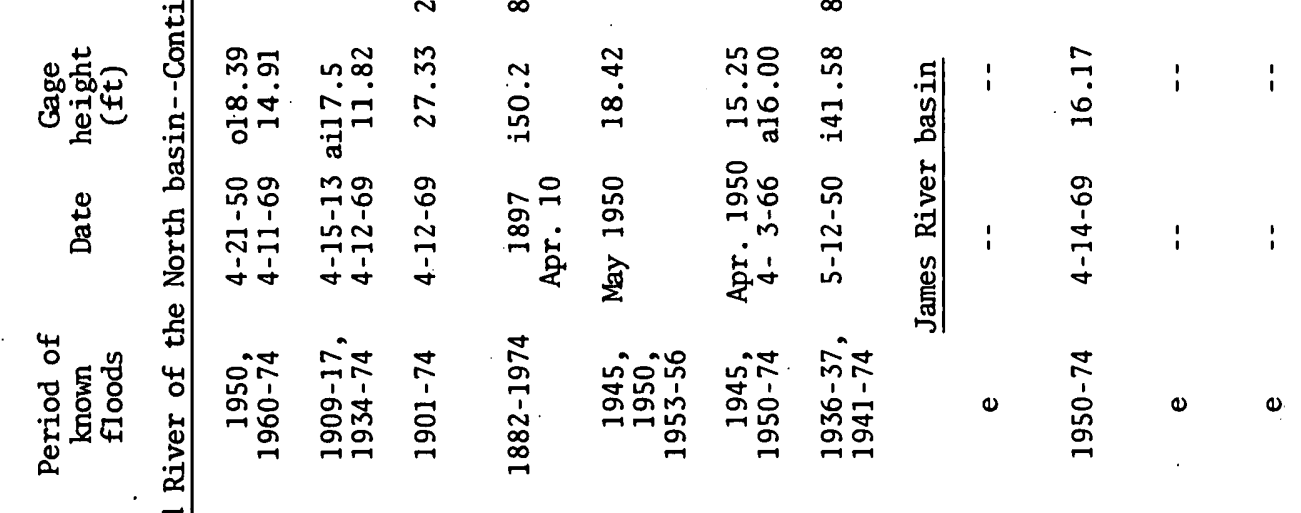
b 究

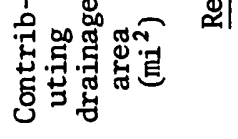

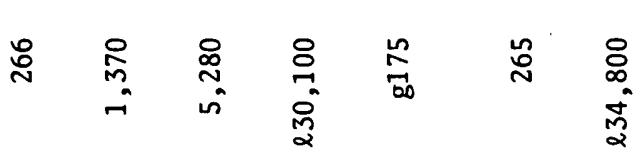

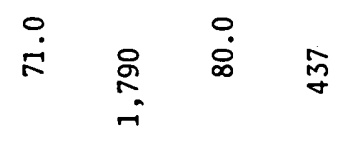

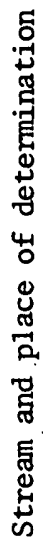

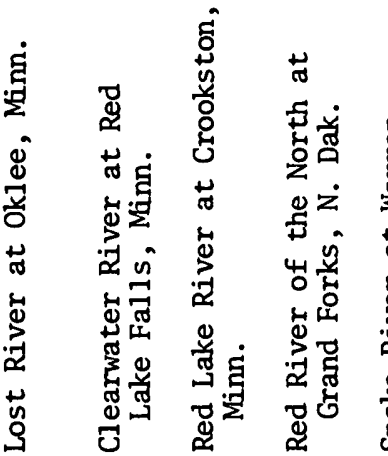

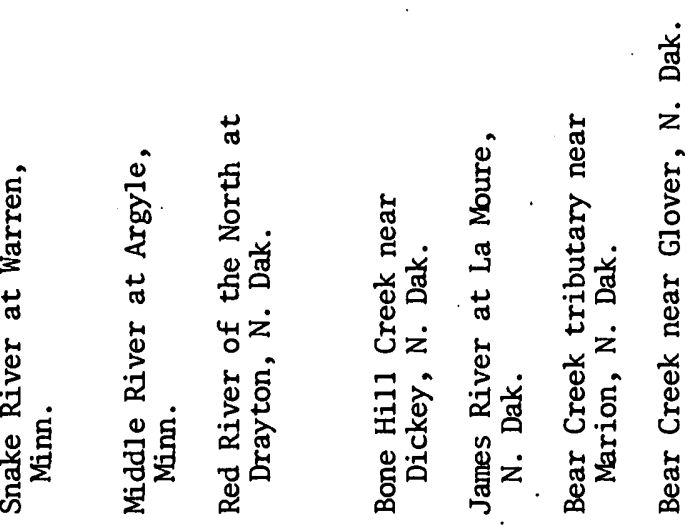
岕运

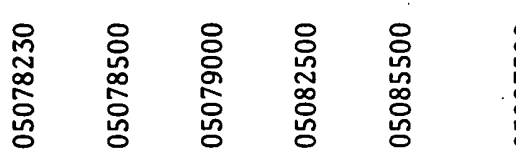

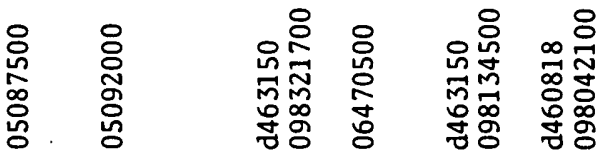
$\dot{2}$ io

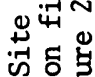
กิ ก เ นึ i⿱ in in 


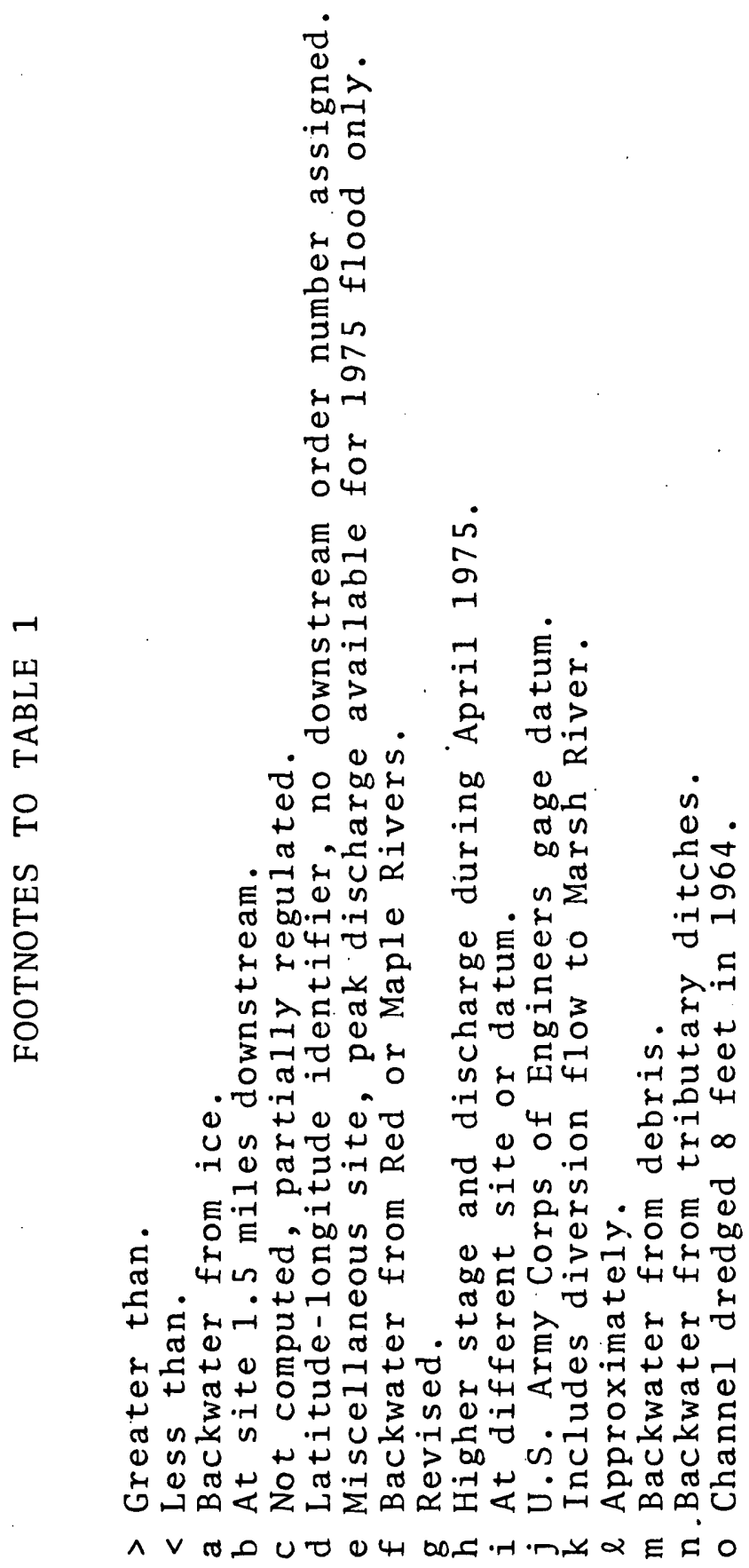


PEAK DISCHARge, IN CUBIC FEET PER SECOND

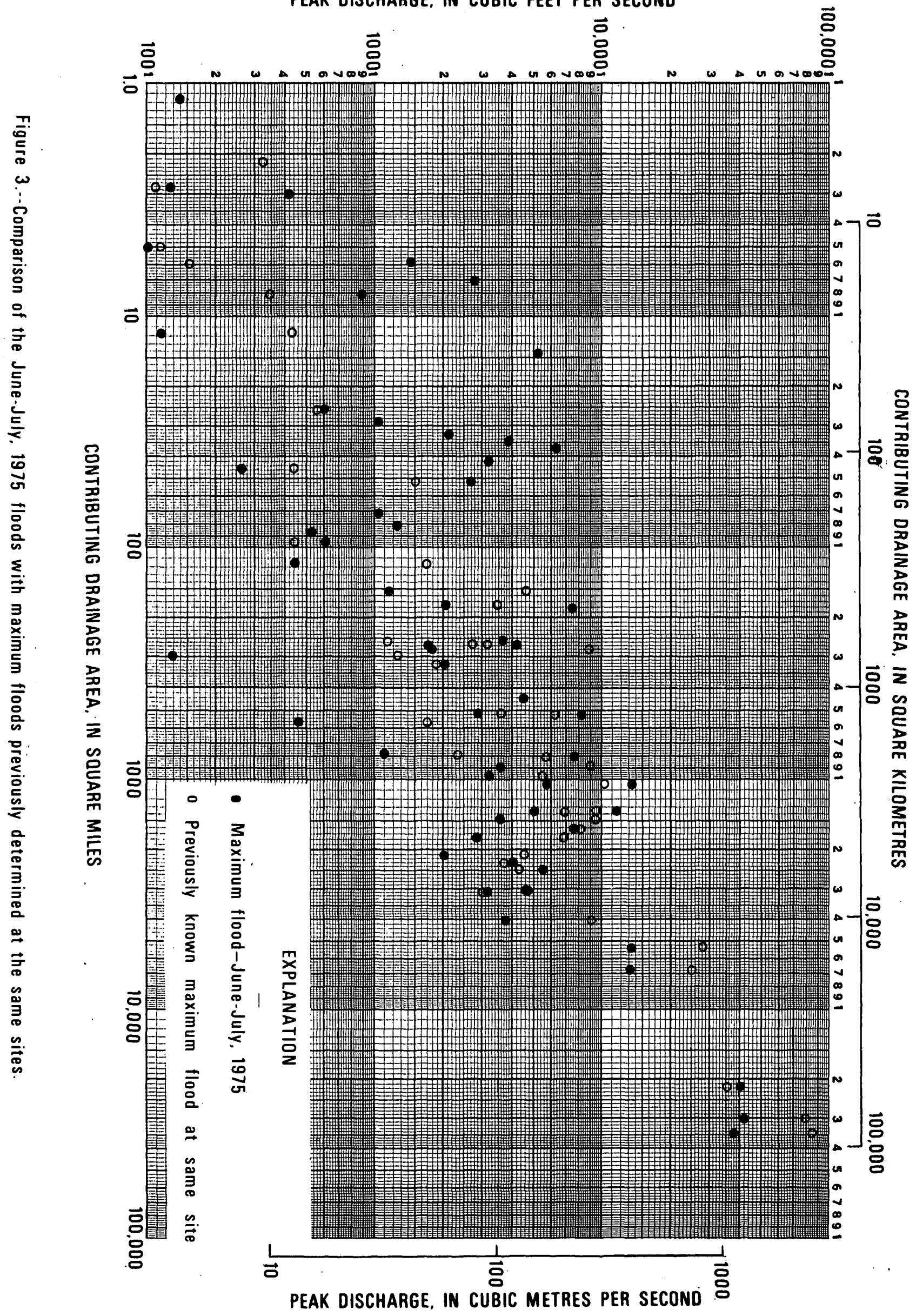




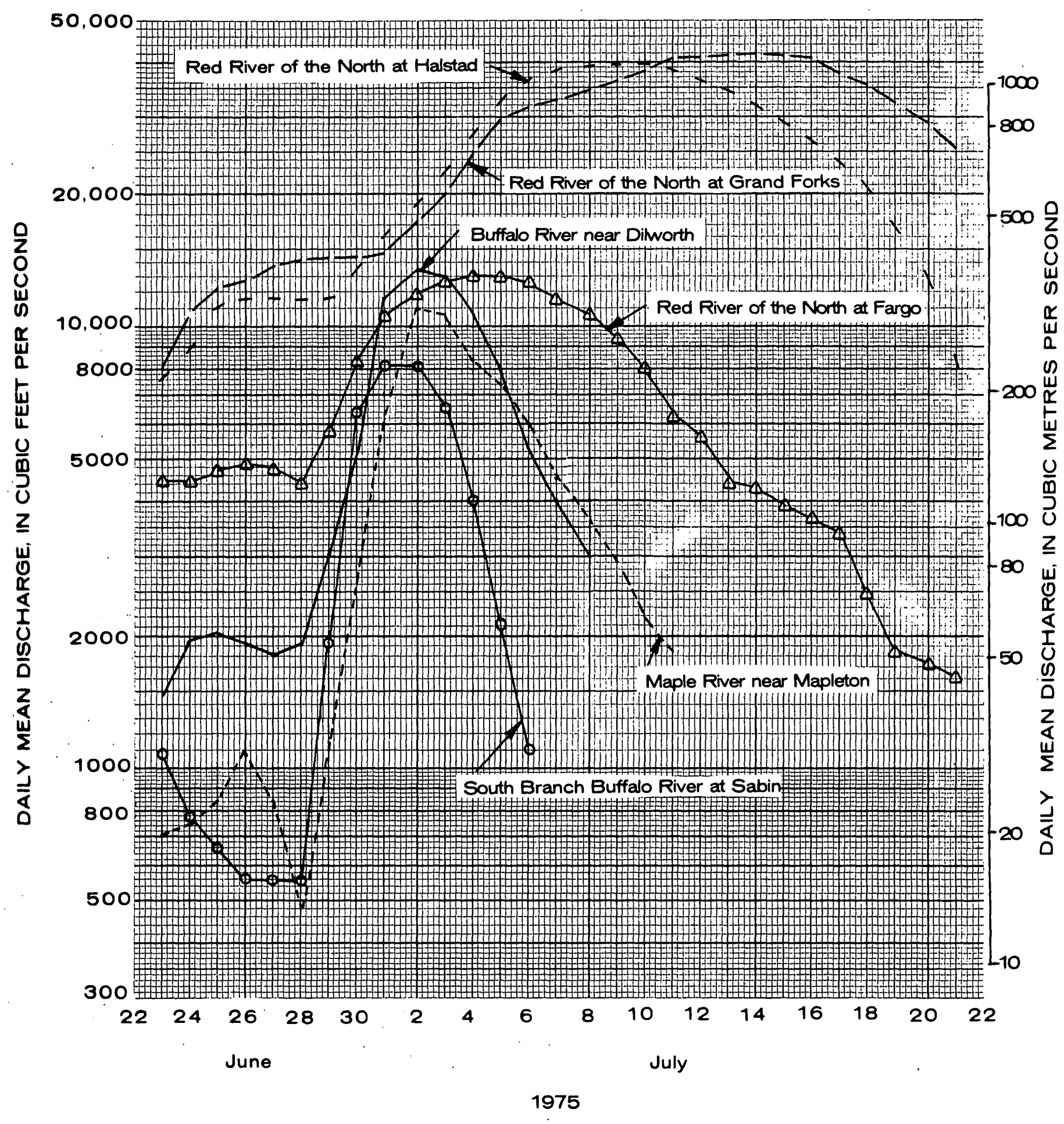

Figure 4.--Flood hydrographs at selected locations. 


\section{Sediment concentrations}

Sediment data were collected at four sites in North Dakota and three sites in Minnesota during the June-July 1975 floods. Available data for evaluating the sediment loads of the major rivers draining the areas flooded are summarized in table 2. A comparison of the discharges listed in table 2 with the peak discharges 1 isted in table 1 shows that all of the sediment data were obtained near the crests of the floods. The sediment concentrations measured during the June-July 1975 floods are not exceptionally high and have been exceeded numerous times in the past.

\section{Remote-sensing data available from EROS Data Center}

The data collected by the EROS Data Center, summarized in table 3, document the areas flooded during June-July 1975. Aerial photography and LANDSAT data are being evaluated for use as a tool for mapping the areas inundated. Beyond the evaluation of short-term flood effects, the LANDSAT data may be useful for studying possible long-term effects like increased soil salinity, erosion, and deposition. 


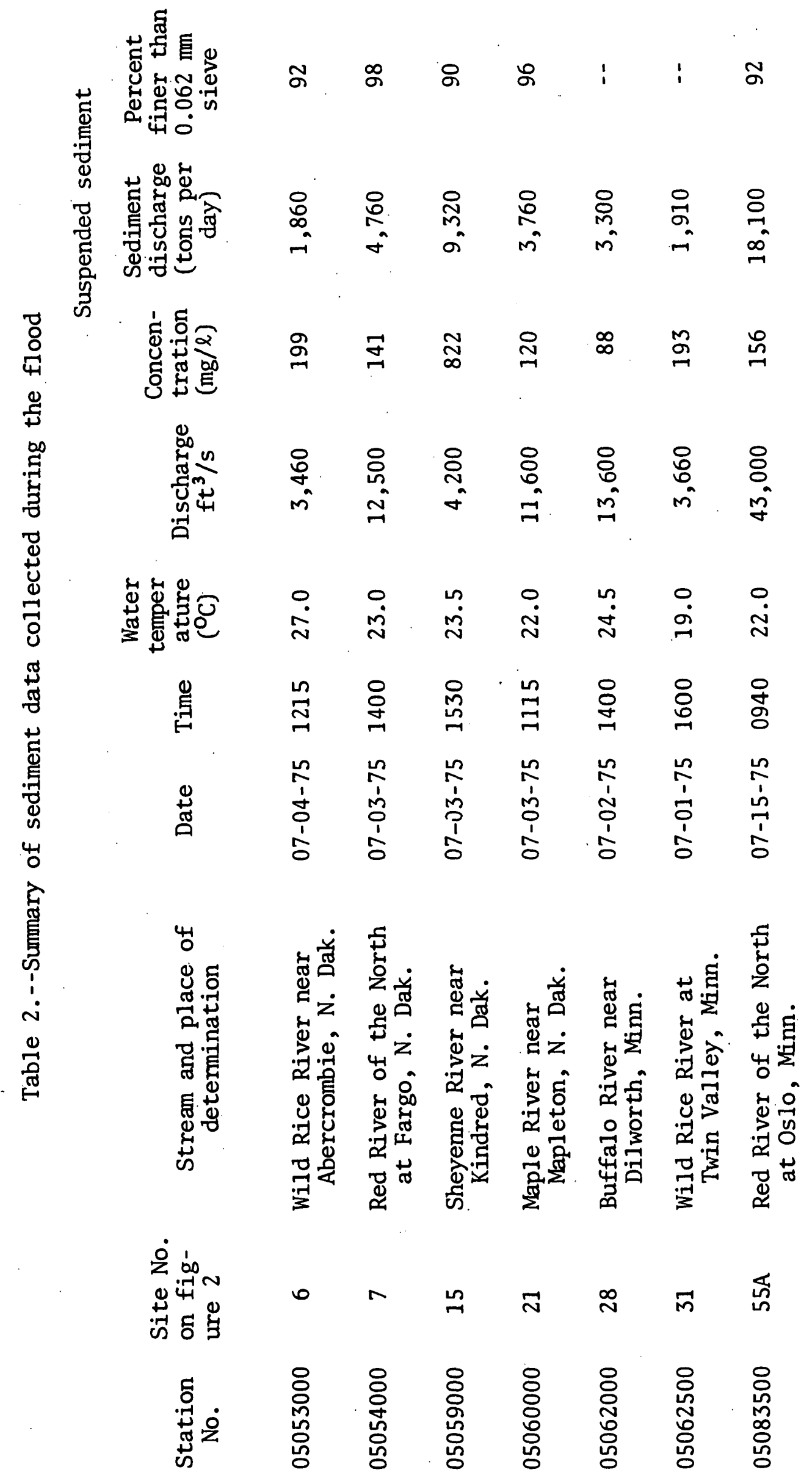


Table 3.--Summary of remote sensing data on 1975 Red River of the North flood available through EROS Data Center (furnished by Applications Assistance Branch,; EROS Data Center, U.S. Geological Survey, Sioux Falls, S. Dak.)

May 12,1975

1. LANDSAT 2 Overpass 0\% Cloud Cover

Identification: E-2110-16370 Fargo-Moorhead area

E-2110-16364 St. Vincent to N. Grand Forks area

E-2110-16373 Wahpeton-Breckenridge area

June 26,1975

1. LANDSAT 1 Overpass $70 \%$ Cloud Cover, Mapleton visible

Identification: E-5068-16260 Mapleton area

July 5, 1975

1. LANDSAT 1 Overpass $10 \%$ Cloud Cover

Identification: E-2164-16372 Fargo-Moorhead area

E-2164-16365 St. Vincent to N. Grand Forks area

E-2164-16374 Wahpeton-Breckenridge area

2. EDC $35 \mathrm{~mm}$, color and color infrared oblique low-altitude aerial slides of West Fargo, Mapleton, and Kindred area.

July 10,1975

1. NASA RB-57 Overflight Mission 315X 1:116,000 scale, metric color infrared imagery, Breckenridge to Canadian Border. Fifty frames of coverage. Frame 1-D. Ro11 8, Frames 019 to 092.

2. EDC $35 \mathrm{~mm}$ color and color infrared ground slides, Fargo-Moorhead, West Fargo area.

July 13,1975

1. EDC Contract Overflight, 1:48,000 scale color infrared imagery. EDC 001, Rol1s 1 and 2. Grand Forks to Breckenridge; 205 frames.

July 14,1975

1. LANDSAT 1 Overpass - Cloud Cover 10\%, Red River Valley visible. Identification: $\quad$ E-5086-16250 Fargo to Grand Forks E-5086-16243 Grand Forks to Canadian Border E-5086-16252 Kindred to Watertown

July 17,1975

1. EDC Contract Overflight, 1:24,000 scale color infrared imagery. EDC 001, Rol1 3, Breckenridge to Grand Forks, along the Red River; 81 frames.

July 25,1975

1. EDC $35 \mathrm{~mm}$ color, and color infrared oblique low-altitude slides of Halstad, West Fargo, Mapleton areas.

September 15, 1975

1. EDC Contract Overflight identical to July 13 th and 17 th Missions. 